\title{
Introduction. Sound, Music and Violence
}

Introduction. Son, musique et violence

\section{Luis Velasco-Pufleau}

\section{(2) OpenEdition}

\section{Journals}

Electronic version

URL: http://journals.openedition.org/transposition/5160

DOI: $10.4000 /$ transposition.5160

ISSN: 2110-6134

\section{Publisher}

CRAL - Centre de recherche sur les arts et le langage

\section{Electronic reference}

Luis Velasco-Pufleau, «Introduction. Sound, Music and Violence », Transposition [Online], Hors-série 2 | 2020, Online since 15 March 2020, connection on 10 December 2020. URL : http://

journals.openedition.org/transposition/5160; DOI : https://doi.org/10.4000/transposition.5160

This text was automatically generated on 10 December 2020.

\section{(c) (†) (อ)}

La revue Transposition est mise à disposition selon les termes de la Licence Creative Commons Attribution - Partage dans les Mêmes Conditions 4.0 International. 


\title{
Introduction. Sound, Music and Violence
}

Introduction. Son, musique et violence

\author{
Luis Velasco-Pufleau
}

1 When, in the third canto of the first part of The Divine Comedy, Virgil leads Dante through the gates of Hell, Dante is frightened not by what he sees, but by what he hears: "Sighs, weeping, loud wailing resounded through the starless air". ${ }^{1}$ The horror is such that Dante sheds tears. The lamentations of the tortured in "strange languages" and "horrible tongues", the "words of pain" and "accents of anger", make a deafening tumult. Faced with the incomprehension of these sounds of fear and pain, Dante asks Virgil, "Master, what is this I hear?" ${ }^{2}$ He feels the pain of the sounds but does not know who makes them or why; he has never heard such sounds before. To be able to attach a meaning to this new world of sound, he must now listen attentively, because listening will be essential in order to know the space, to understand situations and to give meaning to his advancement into the different circles of Hell. This until the last verses, when Dante and his guide find their way out of the lower world through listening: they recognise the hidden path by which they will come out "not by sight, but by the sound of a little stream" ${ }^{3}$ which erodes the rock. By following this path, they return to the bright world and can finally "look again at the stars". ${ }^{4}$

Dante's account of his journey through Hell illustrates the emotional complexity of sound phenomena and shows how listening can become a tool for exploration of, engagement with and sensorial knowledge of the world. This special issue of Transposition explores these subjects through an analysis of the links between sound, music and violence. Six years after the fourth issue was devoted to "Music and Armed Conflicts after $1945 ",{ }^{5}$ this special issue intends to contribute to the considerable growth of interdisciplinary research aimed at understanding collective violence and war through sound and music. In the fields of musicology, ethnomusicology, history, anthropology and sound studies, numerous works have focused as much on the repertoires mobilised in wartime as on the listening experiences of female combatants and civilians in conflict or post-conflict contexts. Svanibor Pettan's pioneering work on 
the Balkan wars ${ }^{6}$ was followed by research on the links between music and violence, ${ }^{7}$ on the sound and musical practices of soldiers during or after the US invasion of Iraq, ${ }^{8}$ as well as a renewed interest in the two World Wars ${ }^{9}$ and the armed conflicts of the nineteenth and twentieth centuries..$^{10}$ These works constitute different entries in an "acoustemology of violence" ${ }^{11}$ In all cases, the topics and methods are as diverse as the many researchers involved.

3 This vast scientific project is above all a collective one and is based on dialogues between researchers working in different countries who mobilise concepts and methodologies belonging to various disciplines in the humanities and social sciences. This issue of Transposition is published in the context of a large social movement which reflects many concerns about neo-liberal reforms in higher education and research in France. To counter the cult of performance, the myth of individual success and the obligation of competition, it is important to insist on the collective dimension of knowledge production. We are treading paths paved by others before us. Our ideas, no matter how original they may seem, are always part of larger constellations and are indebted to the legacy of those who have gone before us and with whom we have developed them. As sociologist Gary Younge recently observed in The Guardian, "Only the privileged and the naive believe people's achievements are purely the product of their own genius". ${ }^{12}$

4 This issue is collective in many ways. The three articles in the first part come from the international workshop Sound and Music in War from the Middle Ages to the Present, which I had the opportunity to organise with Marion Uhlig and Martin Rohde at the Institute for Medieval Studies of the University of Fribourg on 12 and 13 November $2018 .{ }^{13}$ The second part of the issue consists of an interview and three critical commentaries that respond to and extend the statements made. Finally, the third part is comprised of eight essays that comment on certain texts in the issue or develop theoretical, ethical and methodological questions raised by research on music, sound and war. These texts answer two questions: how can the study of sound and music help us to understand collective violence and war? How can the study of war and collective violence help us to understand the importance of musical practices and listening for human beings? ${ }^{14}$

5 However, associating music with the violence, destruction and atrocities of war is not evident in research in humanities and social sciences. As ethnomusicologist Timothy Rice notes, research in the field of what he calls "ethnomusicology in times (and places) of trouble" was scarce before the early 2000s. ${ }^{15}$ This is explained, among other things, by cultural imagination in which music is necessarily associated with "good" things, and by scientific assumptions that music can only be produced in stable social settings. ${ }^{16}$ The texts in this issue contribute to the reconfiguration of these beliefs and, as Morag J. Grant suggests in her essay, to the exploration of the cultural foundations of war and collective violence.

\section{Listening to experiences of armed violence}

The sound narrative of Dante's Inferno evoked at the beginning of this introduction reminds us that sound can be an event that permanently alters a listener's perception of the world around him. The cries and complaints that resonate in the dark air of Hell terrify Dante, while at the same time making him understand that he is entering an 
unknown place. However, sound can also be a process that lasts over time and, through sensory interactions with the listener, transforms their perception of reality.

Dante learns to listen and to evolve in this new world of sound and, through this process, develops new knowledge about how it works and the power dynamics at play. Violence and war shift the limits and thresholds of the usual soundscapes, permanently transforming the listeners' acoustic landmarks and capacities. ${ }^{17}$ The development of these listening habits and skills constitutes a new "auditory regime": the set of techniques, technologies, regulations and shared knowledge that give shape to the listening practices of a given community. ${ }^{18}$

8 Is it possible to better understand the experience of war through auditory regimes? Recent research has explored this question, particularly through the testimonies of combatants. ${ }^{19}$ Michael Guida's essay in this issue highlights a little-examined facet of these narratives: nature's sonic experience by British soldiers mobilised on the Western Front during the First World War. Through the analysis of various sources-diaries, poems and letters-Guida shows how soldiers attach particular importance to bird songs, which frame their listening experiences of trench soundscapes. ${ }^{20}$ In his essay, John Morgan O'Connell discusses the ideas developed by several of the issue's authors, putting them into perspective with his own research on the Battle of Gallipoli (19151916). He explores the links between music and memory, particularly when music is used to both remember and forget, to celebrate victory or to commemorate defeat. ${ }^{21}$

9 The analysis of listening experiences and auditory regimes also made it possible to study non-combatants' experience of armed violence. ${ }^{22}$ This field of research is explored by Nikita Hock in his article on the listening experiences of Warsaw and East Galician Jews in underground shelters during World War II. Through a large body of diaries, Hock succeeds in studying the experiences of civilians-especially women and the elderly-who endured violence and persecution during the Holocaust. ${ }^{23}$

\section{Listening to the sonic remnants of violence}

10 The question of access to sources and their analysis is central to an acoustemology of violence. How to interpret the sonic traces of war in written sources? As Annegret Fauser points out in her essay, these archives constitute mediations of sound experiences from the past, ways of listening and narrating. Drawing on the work of Ana María Ochoa Gautier, she suggests following "an acoustically tuned exploration of the written archive" ${ }^{24}$ in order to explore the sonic remnants of violence, while questioning archives as historically constructed entities, thus privileging the voices of certain types of witnesses. ${ }^{25}$

11 Because violence "is always an attack upon a person's dignity, sense of selfhood, and future", ${ }^{26}$ it upsets and reconfigures the boundaries between sound, noise and silence, between what is sayable and what is not. As Ana María Ochoa Gautier states, "One of the characteristics of violence is the redefinition of acoustic space". ${ }^{27}$ Anna Papaeti explores the modalities and issues for (ethno)musicological research of this redefinition in the context of the use of music for torture. In her essay, she reflects on the consequences of the trauma inflicted by sound and music in detention contexts and on the inherent ethical dimension of witnessing testimonies of victims. ${ }^{28}$ The modalities of what the voice can express, and the boundaries between sound, noise and silence, 
are some of the issues examined by Sarah Kay in her article on the sirventes composed by Bertran de Born, one of the most famous troubadours of the second half of the twelfth century, who is also featured in Dante's Inferno. Mobilising the Lacanian concept of "extimacy", Kay is interested in the sonic dimension of these political songs of love and war that reveal a mediation between noise and music, and reconfigure the poetic transmission of the subjects of love and death..$^{29}$

In his contribution, Martin Daughtry calls for a break with an anthropocentric vision of musical activity; he questions the practical and theoretical frameworks that contribute to fuelling one of the motors of modern violence: the human / nature dualism. ${ }^{30}$ To have separated beings that should have remained together is precisely the reproach that Dante makes to the troubadour Bertran de Born when his spectre appears in the eighth circle of Hell: "His severed head he was holding up by the hair, dangling it from his hand like a lantern"; ${ }^{31}$ divided for sowing discord, his punishment is to proceed with his brain separated from his body. Reflecting on the links between music and violence gives Daughtry the opportunity to think beyond human exceptionalism and to call for a different kind of listening to the sonic remnants of human violence.

Listening to these remnants can raise important ethical questions when researchers are required to talk and work with people who actively participated in the atrocities of war. Although a fundamental topic, explicit examination of it remains largely absent in research on the links between sound, music and violence. Hettie Malcomson discusses this issue, stating the need to respect the humanity and subjectivity of those involved, while avoiding any kind of sensationalism in the process of academic knowledge production. ${ }^{32}$

\section{Violence and the agency of sound and music}

14 All the texts in this issue share a scientific position that is worth recalling: sound and music are not examined as the cause of violent action, but rather as symbolic resources that actors can mobilise in processes or dynamics of violence. The difference is significant and involves the rejection of an ontology of sound and music in which human will is dominated by their supposed powers. Rather, it is a question of understanding how people use music and sound phenomena to give meaning to their reality in contexts of war or to justify acts of destruction and violence.

Music can be a device for projecting, framing and preparing for confrontation with the enemy. The narratives it conveys as well as its sound characteristics can be mobilised by the actors in order to engage in a real or imaginary confrontation. This hypothesis is explored by Victor A. Stoichita in his article on the listening experiences of American soldiers and the Norwegian terrorist Anders Breivik. He shows how the possibility that sound and music are at the origin of a causal chain-the ability that the listener gives sounds, to "transform" the world in which they live-is closely linked to the ontology of the listening experience. ${ }^{33}$ Cornelia Nuxoll explores other issues of musical agency in her essay on her fieldwork in Sierra Leone with former fighters of the Revolutionary United Front (RUF). Her observations point to the emotional complexity of music used in the dynamics of violence as well as in disarmament processes. ${ }^{34}$

The interview I conducted with Jean-Marc Rouillan, a founding member of the armed revolutionary group Action directe (1977-1987), presents the point of view of a protagonist of a kind of political violence. In it he tells how his political engagement 
around 1968 was preceded by a musical engagement, in anticipation of a more direct confrontation with the state. Listening to rock and punk music served as a catalyst for bringing together demands for freedom and autonomous political action. ${ }^{35}$ The interview is followed by three critical commentaries by Matthew Worley (University of Reading), ${ }^{36}$ Timothy Scott Brown (Northeastern University) ${ }^{37}$ and Jeremy Varon (New School). ${ }^{38}$ These texts deepen, criticise or contextualise positions or facts presented by Jean-Marc Rouillan. Whether it is the relationship between music and the collective memory of political struggles, the autonomy sought by the punk movement or the link between rock and capitalism, the commentaries provide valuable counterpoints in grasping the complexity of the historical situation evoked.

17 As Morag J. Grant asserts, "Long after ceasefire, music continues to play an oftentimes fundamental role in celebrating or commemorating wars and warriors, thus functioning as a fundamental toolkit for collective memory which itself, all too often, becomes mobilised in the service of wars yet to come" ${ }^{39}$ By exploring the links between sound, music and violence, this special issue of Transposition questions the ways in which human societies see themselves, build their collective memory and envisage their futures.

\section{BIBLIOGRAPHY}

ALIGHIERI Dante, The Divine Comedy of Dante Alighieri, vol. 1 Inferno, DURLING Robert M. (tran.), New York, Oxford University Press, 1997.

AUDOIN-ROUZEAU Stéphane, BUCH Esteban, CHIMÈNES Myriam and DUROSOIR Georgie (eds.), La Grande Guerre des musiciens, Lyon, Symétrie, 2009.

BIRDSALL Carolyn, Nazi Soundscapes: Sound, Technology and Urban Space in Germany, 1933-1945,

Amsterdam, Amsterdam University Press, 2012.

BROWN Timothy Scott, “Going Underground: The Politics of Free Music around 1968”,

Transposition, no. Hors-série 2, 2020, https://doi.org/10.4000/transposition.4863.

CUSICK Suzanne G., "'You are in a place that is out of the world. . .': Music in the Detention Camps of the "Global War on Terror"', Journal of the Society for American Music, vol. 2, no. 1, 2008, pp. 1-26.

DAUGHTRY J. Martin, “Did Music Cause the End of the World?”, Transposition, no. Hors-série 2, 2020, https://doi.org/10.4000/transposition.5192.

DAUGHTRY J. Martin, Listening to War: Sound, Music, Trauma, and Survival in Wartime Iraq, New York, Oxford University Press, 2015.

EVANS Brad and LENNARD Natasha, Violence: Humans in Dark Times, San Francisco, City Lights Books, 2018.

FAST Susan and PEGLEY Kip, Music, Politics, and Violence, Middletown, Wesleyan University Press, 2012. 
FAUSER Annegret, “Sound, Music, War, and Violence: Listening from the Archive", Transposition, no. Hors-série 2, 2020, https://doi.org/10.4000/transposition.4310.

FAUSER Annegret, Sounds of War: Music in the United States during World War II, New York, Oxford University Press, 2013.

GILMAN Lisa, My Music, my War: The Listening Habits of U.S. Troops in Iraq and Afghanistan,

Middletown, Wesleyan University Press, 2016.

GRANT M. J. and PAPAETI Anna (eds.), "Music and Torture | Music and Punishment", The World of Music, vol. 2, no. 1, 2013, https://www.jstor.org/stable/i24316991.

GRANT Morag Josephine, “On Music and War”, Transposition, no. Hors-série 2, 2020, https:// doi.org/10.4000/transposition.4469.

GRANT Morag Josephine, MÖLLEMANN Rebecca, MORLANDSTö Ingvill, müNZ Simone Christine and NUXOLL Cornelia, "Music and Conflict: Interdisciplinary Perspectives", Interdisciplinary Science Reviews, vol. 35, no. 2, 2010, pp. 183-198.

GUIDA Michael, “Nature's Sonic Order on the Western Front”, Transposition, no. Hors-série 2, 2020, https://doi.org/10.4000/transposition.4770.

HARTFORD Kassandra, "Listening to the Din of the First World War", Sound Studies, vol. 3, no. 2, 2017, pp. 98-114.

HосK Nikita, "Making Home, Making Sense: Aural Experiences of Warsaw and East Galician Jews in Subterranean Shelters during the Holocaust", Transposition, no. Hors-série 2, 2020, https:// doi.org/10.4000/transposition.4205.

JARDIN Étienne (ed.), Music and War in Europe from the French Revolution to WWI, Turnhout, Brepols, 2016.

JOHNSON Bruce and CLOONAN Martin, Dark Side of the Tune: Popular Music and Violence, Farnham, Ashgate, 2009.

KALTENECKER Martin, "Paysage endivisionné. Notes sur les frontières acoustiques de la guerre", Transposition, no. 6, 2016, https://doi.org/10.4000/transposition.1615.

KALTENECKER Martin, “'What Scenes! - What Sounds!' Some Remarks on Soundscapes in War Times”, JARDIN Étienne (ed.), Music and War in Europe from the French Revolution to WWI, Turnhout, Brepols, 2016, pp. 3-27.

KAY Sarah, "Songs of War: The Voice of Bertran de Born", Transposition, no. Hors-série 2, 2020, https://doi.org/10.4000/transposition.3785.

MALCOMSON Hettie, "On Sensationalism, Violence and Academic Knowledge”, Transposition, no. Hors-série 2, 2020, https://doi.org/10.4000/transposition.4931.

MOORE Rachel, Performing Propaganda: Musical Life and Culture in Paris during the First World War, Woodbridge, The Boydell Press, 2018.

NUXoLl Cornelia, "Culprit or Accomplice: Observations on the Role and Perception of Music in Violent Contexts in the Sierra Leone War", Transposition, no. Hors-série 2, 2020, https://doi.org/ 10.4000/transposition.4382.

OCHOA GAUTIER Ana María, "El silencio como armamento sonoro", DE GAMBOA Camila and URIBE María Victoria (eds.), Los silencios de la guerra, Bogotá, Editorial Universidad del Rosario, 2017, pp. 117-157. 
OCHOA GAUTIER Ana María, Aurality: Listening and Knowledge in Nineteenth-Century Colombia, Durham, Duke University Press, 2014.

OCHOA GAUTIER Ana María, “A manera de introducción: la materialidad de lo musical y su relación con la violencia", Trans, no. 10, 2006, https://www.redalyc.org/articulo.oa?id=82201001.

o'ConNelL John Morgan, “Sound Bites: Music as Violence”, Transposition, no. Hors-série 2, 2020, https://doi.org/10.4000/transposition.4524.

o'CONNELL John Morgan and CASTELO-BRANCO Salwa el-Shawan (eds.), Music and Conflict, Urbana, University of Illinois Press, 2010.

PAPAETI Anna, "On Music, Torture and Detention: Reflections on Issues of Research and Discipline", Transposition, no. Hors-série 2, 2020, https://doi.org/10.4000/transposition.5289.

PETIT Élise, Musique et politique en Allemagne : du III ${ }^{e}$ Reich à l'aube de la guerre froide, Paris, Presses de l'Université Paris-Sorbonne, 2018.

PETTAN Svanibor, Music, Politics, and War: Views from Croatia, Zagreb, Institute of Ethnology and Folklore Research, 1998.

PIESLAK Jonathan, Sound Targets: American Soldiers and Music in the Iraq War, Bloomington, Indiana University Press, 2009.

PILZER Joshua D., Hearts of Pine: Songs in the Lives of Three Korean Survivors of the Japanese "Comfort Women", New York, Oxford University Press, 2012.

RICE Timothy, “Ethnomusicology in Times of Trouble”, Yearbook for Traditional Music, vol. 46, 2014, pp. 191-209.

SтогснітA Victor A., "Affordance to Kill: Sound Agency and Auditory Experiences of a Norwegian Terrorist and American Soldiers in Iraq and Afghanistan", Transposition, no. Hors-série 2, 2020, https://doi.org/10.4000/transposition.4065.

SтогснітA Victor A., “Musicopathies. La musique est-elle bonne pour la santé ?", Terrain, no. 68, 2017, pp. 4-25.

SYKES Jim, “Ontologies of Acoustic Endurance: Rethinking Wartime Sound and Listening”, Sound Studies, vol. 4, no. 1, 2018, pp. 35-60.

VARON Jeremy, "Reflections on a Revolutionary and Music", Transposition, no. Hors-série 2, 2020, https://doi.org/10.4000/transposition.4644.

VELASCO PUfLEAU Luis, "From Music to Armed Struggle, from 1968 to Action Directe: An Interview with Jean-Marc Rouillan”, Transposition, no. Hors-série 2, 2020, https://doi.org/10.4000/ transposition.3780.

VELASCO-PUFLEAU Luis, "When Only War Can Kill the Silence: Listening to No One Is Innocent after 13 November 2015”, Volume !, vol. 15, no. 2, 2019, pp. 91a-99a.

VELASCO-PUFLEAU Luis, "No sound is innocent : réflexions sur l'appropriation et la transformation de l'expérience sonore de la violence extrême”, Filigrane, no. 23, 2018, https:// revues.mshparisnord.fr/filigrane/index.php?id=888.

VELASCO-PUflEAu Luis (ed.), "Musique et conflits armés après 1945”, Transposition, no. 4, 2014, https://doi.org/10.4000/transposition.407.

VOLCLER Juliette, Le son comme arme : les usages policiers et militaires du son, Paris, La Découverte, 2011. 
WILLIAMS Gavin (ed.), Hearing the Crimean War: Wartime Sound and the Unmaking of Sense, Oxford, Oxford University Press, 2019.

WORLEY Matthew, "Guitars Give Way to Guns: A Commentary on an Interview with Jean-Marc Rouillan", Transposition, no. Hors-série 2, 2020, https://doi.org/10.4000/transposition.4284.

YOUNGE Gary, "In these Bleak Times, Imagine a World where You Can Thrive", The Guardian, https://www.theguardian.com/commentisfree/2020/jan/10/bleak-times-thrive-last-columnguardian, 10 January 2020, accessed on 25 February 2020.

\section{NOTES}

1. ALIGHIERI Dante, The Divine Comedy of Dante Alighieri, vol. 1 Inferno, DURLING Robert M. (tran.), New York, Oxford University Press, 1997, p. 55.

2. Ibid., p. 57.

3. Ibid., p. 541.

4. Ibid.

5. Velasco-Pufleau Luis (ed.), “Musique et conflits armés après 1945”, Transposition, no. 4, 2014, https://doi.org/10.4000/transposition.407.

6. PETTAN Svanibor, Music, Politics, and War: Views from Croatia, Zagreb, Institute of Ethnology and Folklore Research, 1998.

7. FAST Susan and PEGLeY Kip, Music, Politics, and Violence, Middletown, Wesleyan University Press, 2012 ; Johnson Bruce and Cloonan Martin, Dark Side of the Tune: Popular Music and Violence, Farnham, Ashgate, 2009 ; GRANT Morag Josephine, MÖLLEMANN Rebecca, MORLANDSTÖ Ingvill, MÜNZ Simone Christine and NUXoLl Cornelia, "Music and Conflict: Interdisciplinary Perspectives", Interdisciplinary Science Reviews, vol.35, no. 2, 2010, pp.183-198; o'CONNELL John Morgan and CASTELO-BRAnCo Salwa el-Shawan (eds.), Music and Conflict, Urbana, University of Illinois Press, 2010 ; OCHOA GAUTIER Ana María, “A manera de introducción: la materialidad de lo musical y su relación con la violencia”, Trans, no. 10, 2006, https://www.redalyc.org/articulo.oa?id=82201001 ; SтогснітA Victor A., "Musicopathies. La musique est-elle bonne pour la santé ?", Terrain, no. 68, 2017, pp. 4-25; VOLCLER Juliette, Le son comme arme : les usages policiers et militaires du son, Paris, La Découverte, 2011.

8. See for example, cusick Suzanne G., "'You are in a place that is out of the world. . '? Music in the Detention Camps of the "Global War on Terror"', Journal of the Society for American Music, vol. 2, no. 1, 2008, pp. 1-26; DAUGHTRY J. Martin, Listening to War: Sound, Music, Trauma, and Survival in Wartime Iraq, New York, Oxford University Press, 2015 ; GILMAN Lisa, My Music, my War: The Listening Habits of U.S. Troops in Iraq and Afghanistan, Middletown, Wesleyan University Press, 2016 ; PIESLAK Jonathan, Sound Targets: American Soldiers and Music in the Iraq War, Bloomington, Indiana University Press, 2009.

9. See for example, AUdoIN-ROUZEAU Stéphane, BUCH Esteban, CHIMÈNES Myriam and DUROSOIR Georgie (eds.), La Grande Guerre des musiciens, Lyon, Symétrie, 2009; BIRDSALL Carolyn, Nazi Soundscapes: Sound, Technology and Urban Space in Germany, 1933-1945, Amsterdam, Amsterdam University Press, 2012 ; FAUSER Annegret, Sounds of War: Music in the United States during World War II, New York, Oxford University Press, 2013; HARTFORD Kassandra, "Listening to the Din of the First World War", Sound Studies, vol. 3, no. 2, 2017, pp. 98-114; KALTENECKER Martin, "Paysage endivisionné. Notes sur les frontières acoustiques de la guerre", Transposition, no. 6, 2016, https://doi.org/10.4000/transposition.1615 ; MOORE Rachel, Performing Propaganda: Musical Life and Culture in Paris during the First World War, Woodbridge, The Boydell Press, 2018 ; PETIT Élise, Musique 
et politique en Allemagne : du IIIe Reich à l'aube de la guerre froide, Paris, Presses de l'Université ParisSorbonne, 2018.

10. See for example, GRANT M. J. and PAPAETI Anna (eds.), "Music and Torture | Music and Punishment”, The World of Music, vol.2, no. 1, 2013, https://www.jstor.org/stable/i24316991 ; JARDIN Étienne (ed.), Music and War in Europe from the French Revolution to WWI, Turnhout, Brepols, 2016 ; OCHOA GAUTIER Ana María, "El silencio como armamento sonoro", DE GAMBOA Camila and URIBE María Victoria (eds.), Los silencios de la guerra, Bogotá, Editorial Universidad del Rosario, 2017, pp. 117-157 ; SYKES Jim, “Ontologies of Acoustic Endurance: Rethinking Wartime Sound and Listening", Sound Studies, vol. 4, no. 1, 2018, pp. 35-60 ; wILlIAMs Gavin (ed.), Hearing the Crimean War: Wartime Sound and the Unmaking of Sense, Oxford, Oxford University Press, 2019.

11. OCHOA GAUTIER, "A manera de introducción".

12. YOUNGE Gary, "In these Bleak Times, Imagine a World where You Can Thrive", The Guardian, https://www.theguardian.com/commentisfree/2020/jan/10/bleak-times-thrive-last-columnguardian, 10 January 2020, accessed on 25 February 2020.

13. Full programme available here https://agenda.unifr.ch/e/fr/4349

14. I would like to thank the authors who have contributed to this special issue for their generosity and patience. I would also like to thank the anonymous reviewers who contributed with their comments and suggestions to improve the texts of this issue. Finally, I would like to express my gratitude to the members of the Transposition editorial board for their participation in this project as well as to the colleagues and friends who supported my research at the University of Fribourg, the Fondation Maison des sciences de l'homme (FMSH) and the University of Bern.

15. RICE Timothy, "Ethnomusicology in Times of Trouble", Yearbook for Traditional Music, vol. 46, 2014, pp. 191-209.

16. Ibid., p. 192.

17. KALTENECKER Martin, “'What Scenes! - What Sounds!' Some Remarks on Soundscapes in War Times", JARDIN Étienne (ed.), Music and War in Europe from the French Revolution to WWI, Turnhout, Brepols, 2016, pp. 3-27.

18. DAUGHTRY, Listening to War, p. 124.

19. DAUGHTRY, Listening to War ; GILMAN, My music, my War ; PIESLAK, Sound Targets.

20. GUIDA Michael, "Nature's Sonic Order on the Western Front", Transposition, no. Hors-série 2, 2020, https://doi.org/10.4000/transposition.4770.

21. o'ConNELL John Morgan, "Sound Bites: Music as Violence”, Transposition, no. Hors-série 2, 2020, https://doi.org/10.4000/transposition.4524.

22. See for example, SYKES, "Ontologies of acoustic endurance" ; PILZER Joshua D., Hearts of Pine: Songs in the Lives of Three Korean Survivors of the Japanese "Comfort Women", New York, Oxford University Press, 2012; VELASCO-PUFLEAU Luis, "No sound is innocent: réflexions sur l'appropriation et la transformation de l'expérience sonore de la violence extrême", Filigrane, no. 23, 2018, https://revues.mshparisnord.fr/filigrane/index.php?id=888 ; velASCO-PUFLEAU Luis, “ When Only War Can Kill the Silence: Listening to No One Is Innocent after 13 November 2015", Volume!, vol. 15, no. 2, 2019, pp. 91a-99a.

23. носк Nikita, "Making Home, Making Sense: Aural Experiences of Warsaw and East Galician Jews in Subterranean Shelters during the Holocaust", Transposition, no. Hors-série 2, 2020, https://doi.org/10.4000/transposition.4205.

24. OCHOA GAUTIER Ana María, Aurality: Listening and Knowledge in Nineteenth-Century Colombia, Durham, Duke University Press, 2014, p. 3.

25. FAUSER Annegret, "Sound, Music, War, and Violence: Listening from the Archive", Transposition, no. Hors-série 2, 2020, https://doi.org/10.4000/transposition.4310. 
26. EVANS Brad and LENNARD Natasha, Violence: Humans in Dark Times, San Francisco, City Lights Books, 2018, p. 3.

27. "Una de las características de la violencia es la redefinición del espacio acústico”, осноА GAUTIER, "A manera de introducción".

28. PAPAETI Anna, "On Music, Torture and Detention: Reflections on Issues of Research and Discipline”, Transposition, no. Hors-série 2, 2020, https://doi.org/10.4000/transposition.5289.

29. KAY Sarah, "Songs of War: The Voice of Bertran de Born", Transposition, no. Hors-série 2, 2020 , https://doi.org/10.4000/transposition.3785.

30. DAUGhTRY J. Martin, "Did Music Cause the End of the World?", Transposition, no. Hors-série 2, 2020, https://doi.org/10.4000/transposition.5192.

31. ALIGHIERI, The Divine Comedy of Dante Alighieri, p. 439.

32. MALCOMSON Hettie, "On Sensationalism, Violence and Academic Knowledge", Transposition, no. Hors-série 2, 2020, https://doi.org/10.4000/transposition.4931.

33. зтогснітA Victor A., "Affordance to Kill: Sound Agency and Auditory Experiences of a Norwegian Terrorist and American Soldiers in Iraq and Afghanistan", Transposition, no. Horssérie 2, 2020, https://doi.org/10.4000/transposition.4065.

34. NUXOLL Cornelia, "Culprit or Accomplice: Observations on the Role and Perception of Music in Violent Contexts in the Sierra Leone War", Transposition, no. Hors-série 2, 2020, https://doi.org/ 10.4000/transposition.4382.

35. Velasco PUfleAu Luis, "From Music to Armed Struggle, from 1968 to Action Directe: An Interview with Jean-Marc Rouillan", Transposition, no. Hors-série 2, 2020, https://doi.org/ 10.4000/transposition.3780.

36. WORLEY Matthew, "Guitars Give Way to Guns: A Commentary on an Interview with Jean-Marc Rouillan", Transposition, no. Hors-série 2, 2020, https://doi.org/10.4000/transposition.4284.

37. BRown Timothy Scott, "Going Underground: The Politics of Free Music around 1968", Transposition, no. Hors-série 2, 2020, https://doi.org/10.4000/transposition.4863.

38. VARON Jeremy, "Reflections on a Revolutionary and Music", Transposition, no. Hors-série 2, 2020, https://doi.org/10.4000/transposition.4644.

39. GRANT Morag Josephine, "On Music and War", Transposition, no. Hors-série 2, 2020, https:// doi.org/10.4000/transposition.4469.

\section{ABSTRACTS}

Listening can become a tool for exploration of, engagement with and sensorial knowledge of the world. Music can be a device for projecting, framing and preparing for confrontation with the enemy. How can the study of sound and music help us to understand collective violence and war? How can the study of war and collective violence help us to understand the importance of musical practices and listening for human beings? This special issue of Transposition explores these questions through an analysis of the links between sound, music and violence.

L'écoute peut devenir un outil d'exploration, d'engagement et de connaissance sensible du monde. La musique peut être un moyen de projeter, d'encadrer et de préparer l'affrontement avec l'ennemi. De quelle façon l'étude du son et de la musique peut-elle aider à comprendre la violence collective et la guerre? Comment l'étude de la guerre et de la violence collective peut- 
elle aider à comprendre l'importance des pratiques musicales et de l'écoute pour les êtres humains? Ce numéro hors-série de Transposition propose d'explorer ces questions à partir de l'analyse des liens entre son, musique et violence.

\section{INDEX}

Keywords: agency, auditory regime, Dante, listening, music, sound, violence, war Mots-clés: agentivité, Dante, écoute, guerre, musique, régime d'audition, son, violence

\section{AUTHOR}

\section{LUIS VELASCO-PUFLEAU}

Luis Velasco-Pufleau is a musicologist and sound artist. He is currently a SNSF researcher at the University of Bern (Walter Benjamin Kolleg / Institute of Musicology). His work critically reflects on the relationship between music and politics in contemporary societies. As a researcher and sound artist, he is interested in exploring innovative forms of writing at the crossroads of artistic creation and research in the humanities and social sciences.

ORCID: https://orcid.org/0000-0002-1330-974X 